\author{
Viktor Vechersky, \\ Ph.D. in Architecture, \\ Associate Professor, \\ Kyiv National University \\ of Culture and Arts, \\ Kyiv, Ukraine \\ vechersky.v@gmail.com \\ https://orcid.org/0000-0002-5221-3556
}

\title{
RESULTS OF UKRAINIAN ARCHITECTURE STUDY OF HETMAN PERIOD
}

The article is devoted to the results of the study of Architecture in Ukraine of XVII-XVIII centuries, conducted over the last century. The relevance of the study is conditioned by the necessity of forming the history of the national architecture and monumentology on modern methodological principles, according to which all phenomena and processes of the corresponding age within the current territory of the state are studied, regardless of the ethnic, confessional or state origin of those or other phenomena and artifacts. The main objective of the study is to synthesize the results of the study of the historical and architectural process during the Hetmanate period, including clarifying the stages of the development of architecture; identification of regional peculiarities; the establishment of the role and place of the architectural heritage of the Hetmanate period in the further development of Ukrainian architecture and urbanism and its place in the context of the development of European architecture. The methodology of the research is to apply the methods of theoretical research, namely, the historical method in the systematic approach, when the object of study is the architecture of a certain period is considered in the occurrence and development. The system approach consists in complex studying of the object as a certain unity of the multi element system, for studying which methods of structural-genetic analysis and synthesis with decomposition of the system on the subsystems, which are studied autonomously, with their subsequent coordination, are applied. The scientific novelty consists in revealing the regularities of the formation and development of Ukraine's architecture of Hetmanate period, determining the nature and basic features of these processes, more thoroughly clarifying regional differences, defining the European and Eurasian context of the development of architecture in that time in Ukraine. The findings and conclusions of the study allow us to consider the architecture of Ukraine as an independent phenomenon, and not as a derivative of the architecture of the Moscow kingdom, the Russian Empire or the marginal phenomenon of the

Central European architectural process. The high level of self-sufficiency of Ukrainian architecture is proved on the basis of the development and transformation of autochthonous traditions and selective learning of the experience of other cultures. Examined in science are incorrect ideas about defining the dominant style of architecture as a baroque. The simultaneous existence of two stylistic currents, namely Baroque, Western origin, and Renaissance-Baroque synthesis, which became the result of the development of autochthonous architectural traditions, was proved. 
Key words: architectural heritage, Hetmanate period, history of architecture, stages of development, European context.

The relevance of the study is caused by a necessity of the forming the history of national architecture and monument studies based on the modern methodology. According to these new methodological principles we study all events and processes of relevant periods within the present territory of the state despite the ethnic, confessional or political origin of the various events, artefacts. Despite the fact that this statement is not new it is still controversial in the field of Ukrainian monument studying and architecture studying. That is why now we should precisely define: all that was built on the territory of Ukraine is Ukrainian architectural heritage, therefore we ought to study, preserve and include this architectural heritage into the modern context of Ukrainian life. Our preliminary studies and this article are based on these ideas.

Statement of the problem. Ukrainian restorers have fulfilled scientificresearch, project-search and restoration works at numerous architectural and town-planning monuments of XVII-XVIII centuries for the late period, they have explored many new facts and architectural peculiarities, presented and proved new attributions of some monuments (From the History of Ukrainian Restoration, 1996). All these need to be comprehended and generalized.

The range of problems in this article includes the researches of the history of Ukrainian architecture and town-planning which have been conducted by the author since 1984. The results of these researches have been applied in the range of our publications in the leading scientific and popular scientific editions, at numerous conferences, as well as during the practical actions aimed at the protection of architectural and town-planning heritage (Victor Vechersky, 2008).

\section{Analysis of recent research and publications in which started the solution of the problem.}

Our study of architectural and town-planning heritage of Hetmanate period enlarge, complete and concretize the previous studies of the following researchers in this field: G. Pavlutsky (2007), I. Hrabar (1997), F. Ernst (1919), M. Makarenko (1908), V. Shcherbakivsky (2015), V. Sichynsky (1956), O. Ohloblyn (2008), S. Taranushenko (2014), M. Tsapenko (2005), G. Lohvyn (2002), P. Yurchenko (1970), D. Yablonsky (1955), S. Kilesso (2000), as well as colleagues - V. Lenchenko (1997), L. Prybeha (2007), T. Kilesso (1995), S. Yurchenko (2015), and others.

After analyzing the literature, studying the archival materials, as well as summarizing the results of field studies, analytic working with state registers (lists, enumerations) of architectural and town-planning heritage (The State Register of the National Heritage, 1999) we concluded that in spite of the 150-year-old history of researches the architecture of Ukraine in the times of Hetmanate has not been studied properly, in literature it is shown partially and often even erroneously (The History of Ukrainian Culture , 2003, pp. 835-854). 
The most important achievements which we can use from the previous stages of the architectural studies development in the this field are:

creating the factual basis of Ukrainian architecture history;

realization and scientific grounds for the fact that in Ukraine its own original architecture interrelated with European one was developing progressively on the principles of succession;

clarifying the fundamental difference between Ukrainian architecture and architecture of neighboring countries (Russia, Poland etc.) and impossibility to apply stages of their development and definition of their stylistics for Ukrainian architecture;

attempts to give reasoned stylistic definitions;

forming the territorial principle of regarding the architectural phenomena and compositions (Tymofiienko 2003, pp. 193-243).

\section{Bold unsolved aspects of the problem.}

The formation of architecture in the period of Hetmanate on the territory of the whole Ukraine has been explored incompletely. Therefore, our aim is to discover earlier unknown and specify well-known facts and regularities about the processes of formation and development of the architecture on the territory of Ukraine in the given period, to define the character and main peculiarities of these processes, to clarify the regional distinctions in architecture. Completely new and utterly important in this monograph is that we study European and Eurasian context of architectural development in Ukraine.

\section{Formulating the goals of the article.}

The main objective of the study is to generalize the results of studies of historical and architectural process in the period of Hetmanate, including specification the stages of architectural development; detection the regional peculiarities of architecture; determination the role and the place of architectural heritage in the times of Hetmanate in the further development of Ukrainian architecture and urbanization.

\section{The main material.}

Social and cultural changes which occurred as a result of national and social revolution in 1648-1654 noticeably influenced the architectural development. The most important social achievements after the revolution became the gaining of autonomy and extending Ukrainian ethnic territory to the East and South with the further town-planning developing of the vast, wealthy, almost uninhabited territories of the former Wild Field - Sloboda Ukraine (Slobozhanschina). These two intense social processes stimulated the architectural development.

The heritage of previous years (XVI - mid of XVII centuries) within the system of fortification, typology of buildings and organization of construction provided a basis for the architectural development. The architectural heritage of Kievan Russia mediated by Polish-Lithuanian period, enriched by west-European Renascence achievements, greatly influenced the formation of the new tendencies. 
The following main features are typical for the architectural activity as a whole:

its significant development in the Dnieper region, Left-bank Ukraine and Sloboda Ukraine along with decline in other regions; Kyiv became the center of this activity and remained it till the end of this period;

unexampled, comparing with other periods, development of stone construction;

the leading role of a customer in defining the architectural program;

partial preservation of team-work methods under the full financial and legal liability of the foreman - the head of the workmen's cooperative association;

combining an architect, an artist, an entrepreneur, a contractor, a producer, a provider of construction material in one person;

gradual, during the given period, change-over from medieval methods of professional work (according to the samples indicated by the customer) to elaboration and approbation the design drawings and accomplishing the construction works according to them;

increasing role of individual architectural art in the end of the given period - bringing to the forefront the figure of professionally qualified architect in the field of stone elitist construction; the formation of a modern notion about the profession of an architect.

Today, having studied architectural monuments of the period more thoroughly (including those monuments which were discovered by the archaeologists in the last decade and particularly those which appeared in the time of Hetman Mazepa's ruling), having clarified typological and stylistic development of architecture in XVII-XVIII centuries in more detail, we specify the stages of architectural development due to the emphasizing Mazepa's stage as a period of crystallization of the national architectural style and the most significant achievements. Taking this into consideration, we defined four stages of architectural development in the times of Hetmanate with the following chronological limits:

1. The Early Stage: $1648-1687$ years;

2. Mazepa's Stage: 1687-1709 years;

3. The Stage of Stagnation: 1709-1750 years;

4. The Final Stage: 1750-1781 years.

The Ukrainian architecture in the times of Hetmanate was developing in the respective context. It was determined by geographical and cultural reasons, at that two factors played a crucial part. Firstly, the location of our country at the great Eurasian geopolitical intersection, where political and cultural influence of the Ottoman and the Holy Roman Empire, Polish-Lithuanian Commonwealth, Moscovia and then Russian Empire met. Secondly, Ukrainian lands traditionally belonged to the Orthodox world, which is based on the Byzantine tradition, however at the same time they bordered on other areas of great world religions Latin Christianity (Catholicism) and Protestantism on the West, Islam on the 
South. All these state and religious formations during XVI-XVIII centuries elaborated and developed their own specific architecture based mostly on the heritage of Byzantium and Italian Renascence. These neighboring architectural traditions influenced the architectural processes in Ukraine to a greater or lesser extent.

In the latter half of XVII - the first half of XVIII centuries architecture was developing on basis of the heritage of Italian Renascence in the mainstream of Baroque stylistics in all European countries (Norwich, 1979, pp. 172-191). Besides two main All-European tends of Baroque - classical and dynamic, we can define national differences of Baroque style in different countries, such differences are often quite outstanding like in Austria (Kluckert, 2008, pp. 50-54), France or Russia. At that in Moscovia in the latter half of XVII - the beginning of XVIII centuries we can observe only separate features of Baroque style which laid on the architectural structures of indigenous origin in peculiar way. Particularly Baroque stylistics became expressively apparent in Russia later than in other European countries - only in thirties of XVIII century and its lifetime wasn't long - no more than forty years (up to 1770-ies).

Considerable activity of town-planning processes in the Dnieper region, Sloboda Ukraine and Northern Left-bank Ukraine. Unlike in the towns of these regions, we can observe that stagnant phenomena and conservative tendencies prevailed in town-planning of West Ukraine in this period.

Town-planning processes in that period resulted in formation of the planning and spatial framework and main features of the architectural sphere of Ukrainian towns with their natural semantic completeness, hierarchical composition, harmonious connection with natural landscape, aesthetic expressiveness (Fig. 1). Volumetric and spatial town construction formed in that period determined to a considerable extent the development of towns in the following periods and today it is an integral part of the national town-planning heritage.

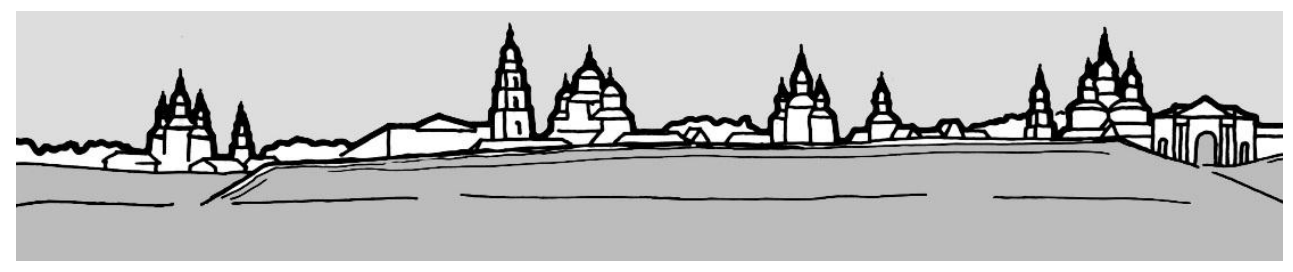

Fig. 1. Panorama of the city of Hlukhiv in the 70's. XVIII century. Reconstruction by $\vee$. Vechersky

Fortification complexes which were a basic town-planning factor had vital meaning in that period (Fig. 2). In the given period these complexes were gradually 


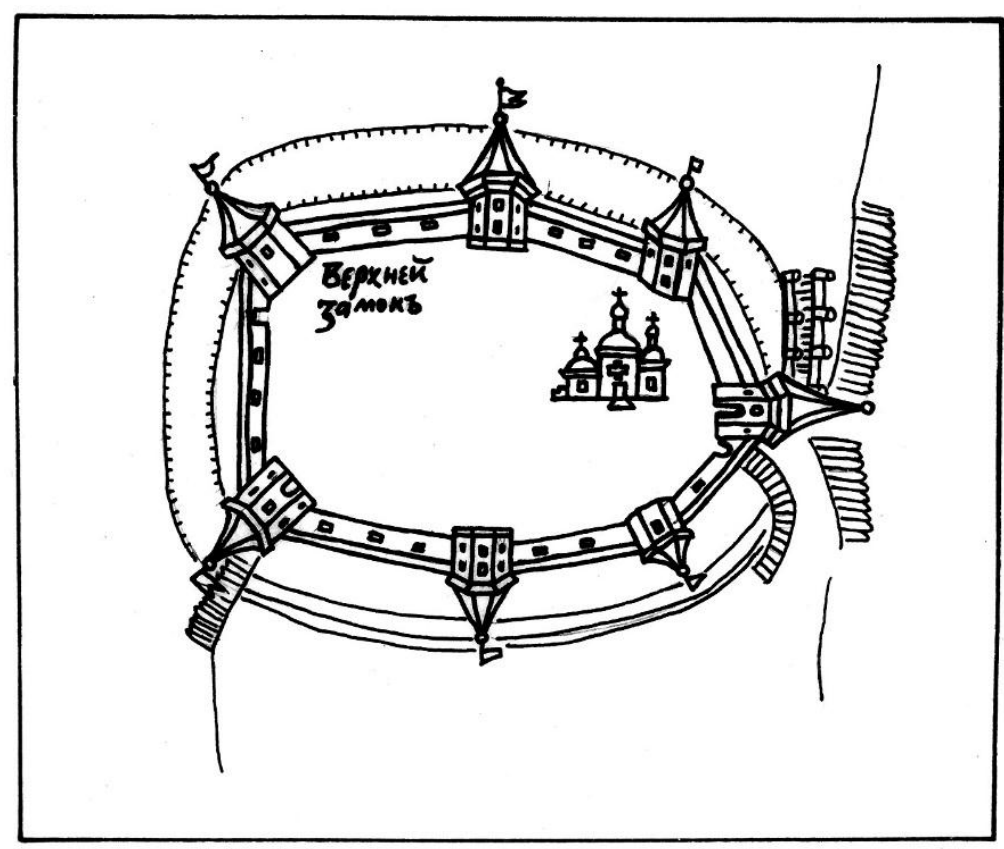

Fig. 2. The image of the Upper Castle in Chernihiv on the "Abris of Chernigov" in 1706.

Drawing by $\vee$. Vechersky

losing their architectural dominants and accents as a result of liquidation of the towers and increasing the solidity of defensive wall, bulwarks and ravelins. At the same time, their town-planning role as elements which divide and demarcate the structural parts of town area was increasing (Fig. 3).

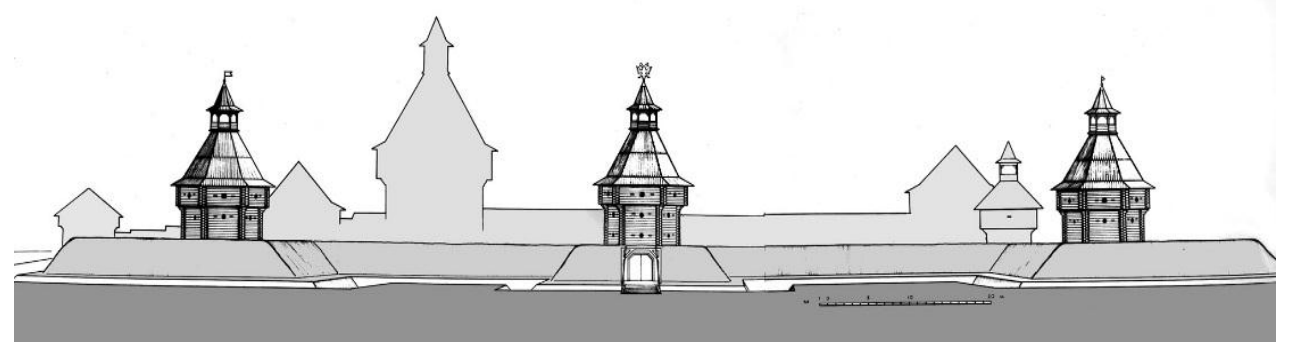

Fig. 3. Panorama of the fortifications of Putivl in the 80's. XVII century. Reconstruction by $\vee$. Vechersky

The political changes in the latter half of XVIII century reduced to the gradual decline of fortification complexes and their further disappearance. Nevertheless, their signs are preserved in the planning, as well as in volumetric and spatial structure of the most historical settlements in Ukraine, and today they determine 
the town-planning compositions of their centers in many respects (International Conference on the Problems of Fortifications in Ukraine, 1993, p. 12).

The concentricity of building up is typical for the monastic complexes of that period. There were two principal versions of arranging the main functional zones - concentric and successive. Roman Catholic and Eastern Catholic (Uniate) cloisters on the West and Orthodox cloisters in other regions were developing according to their own traditions inhere to every religion. We distinguish the following composition types of cloisters: Roman Catholic closed, compact and blocked; Orthodox - centric pavilion (Fig. 4) and line (frontal) pavilion; Eastern Catholic (Uniate) - blocked and line (frontal) pavilion. The appearance of the new architectural dominants resulted in the activation of the monastic complexes role in volumetric and spatial composition of the settlements.

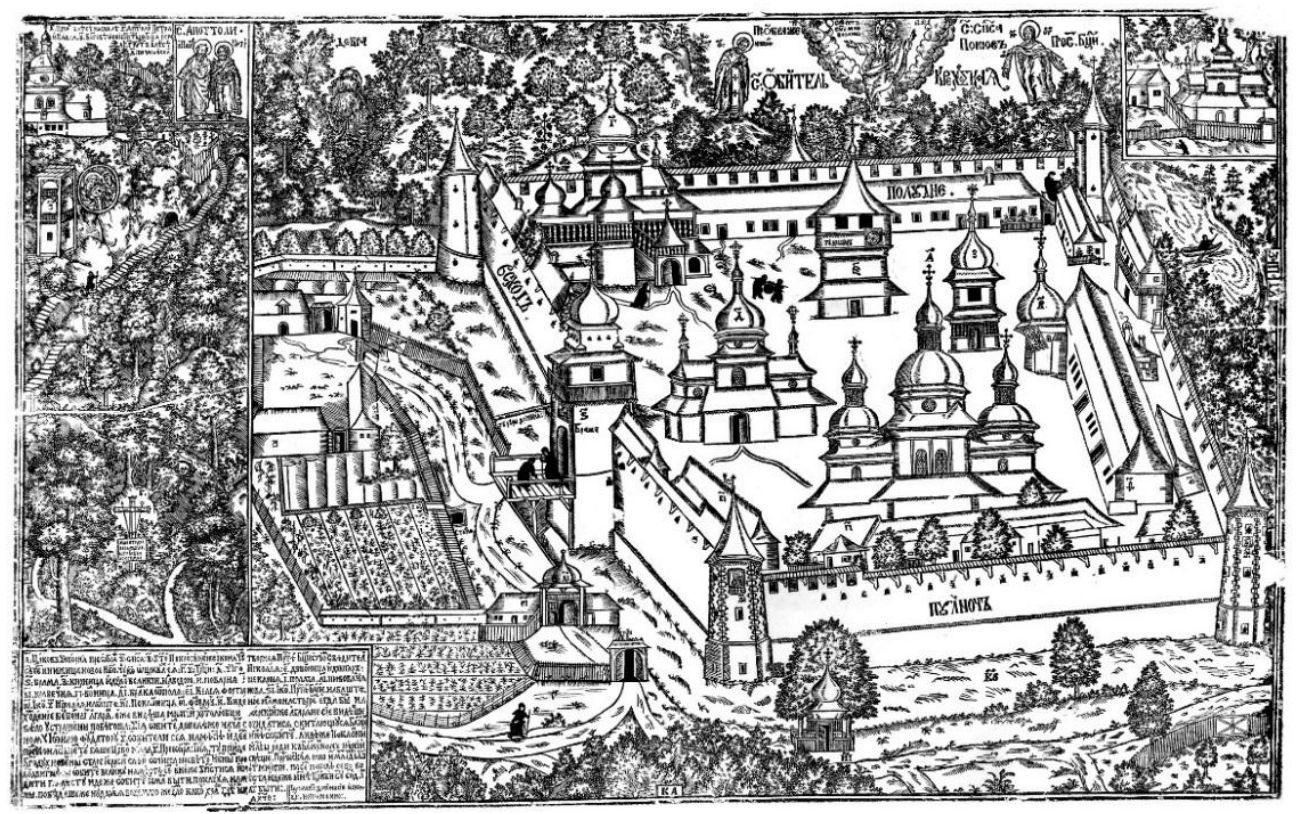

Fig. 4. Krekhiv Orthodox Monastery.

Engraving by D. Sinkevich 1699

We can observe the common peculiarities in spatial composition and planning of all complexes (fortification and monastic) of that period: mastering the landscape areas of high composition activity; dominating role in building-up and landscape; the isolation of inner space from the environment; the strict hierarchical structure of buildings and constructions (Fig. 5); tendency to regularity in planning and building (Fig. 6).

This period was marked by the development of planning, volumetric and spatial structures of buildings which belonged to different functional types inhabitable, public (sacral, administrative, educational), defensive, industrial etc. 
Nevertheless, the leading functional type was temples, which embodied the most important social functions.

We can define two main typological groups in Orthodox ecclesiastic construction which were developing the most in that time.

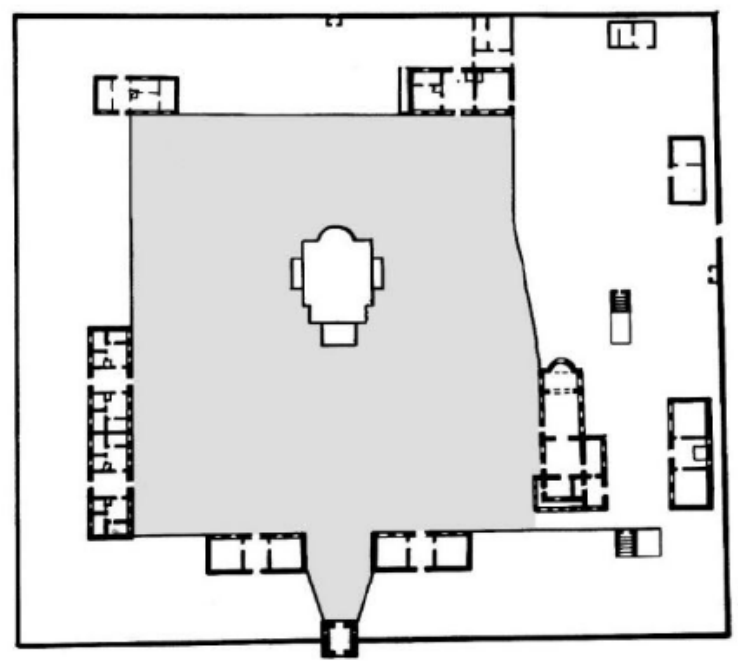

Fig. 5. Plan of the Maksakiv Orthodox Monastery. Reconstruction by $\mathrm{V}$. Vechersky

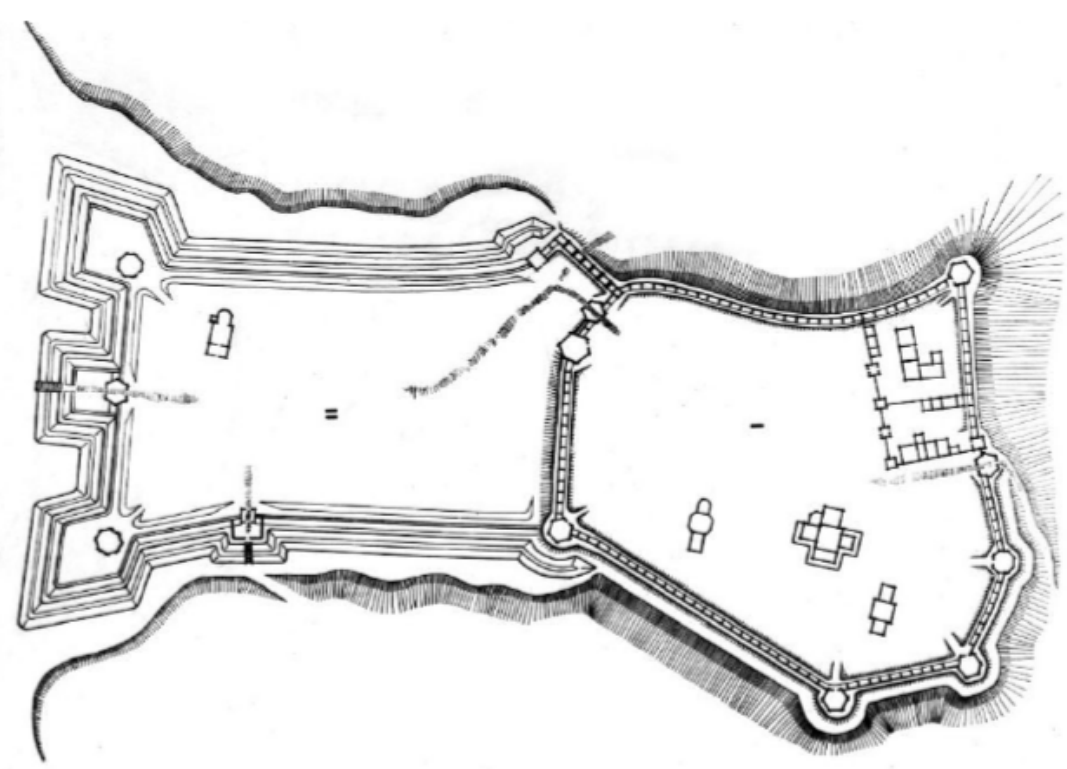

Fig. 6. Regularity in fortification architecture: plan fortifications of the Old Town and the New Town in Putivl in the 80's. XVII century.

Reconstruction by $\mathrm{V}$. Vechersky 
The first group revives the volumetric and spatial structures of stone temples which were typical for Kyivan Rus and shows the influence of western Baroque. We can find such temples only in stone architecture; they do not have prototypes in wooden ecclesiastic architecture. They are three-naved, with a transept, six-pillar, cross-domed, multi domed (Fig. 7).

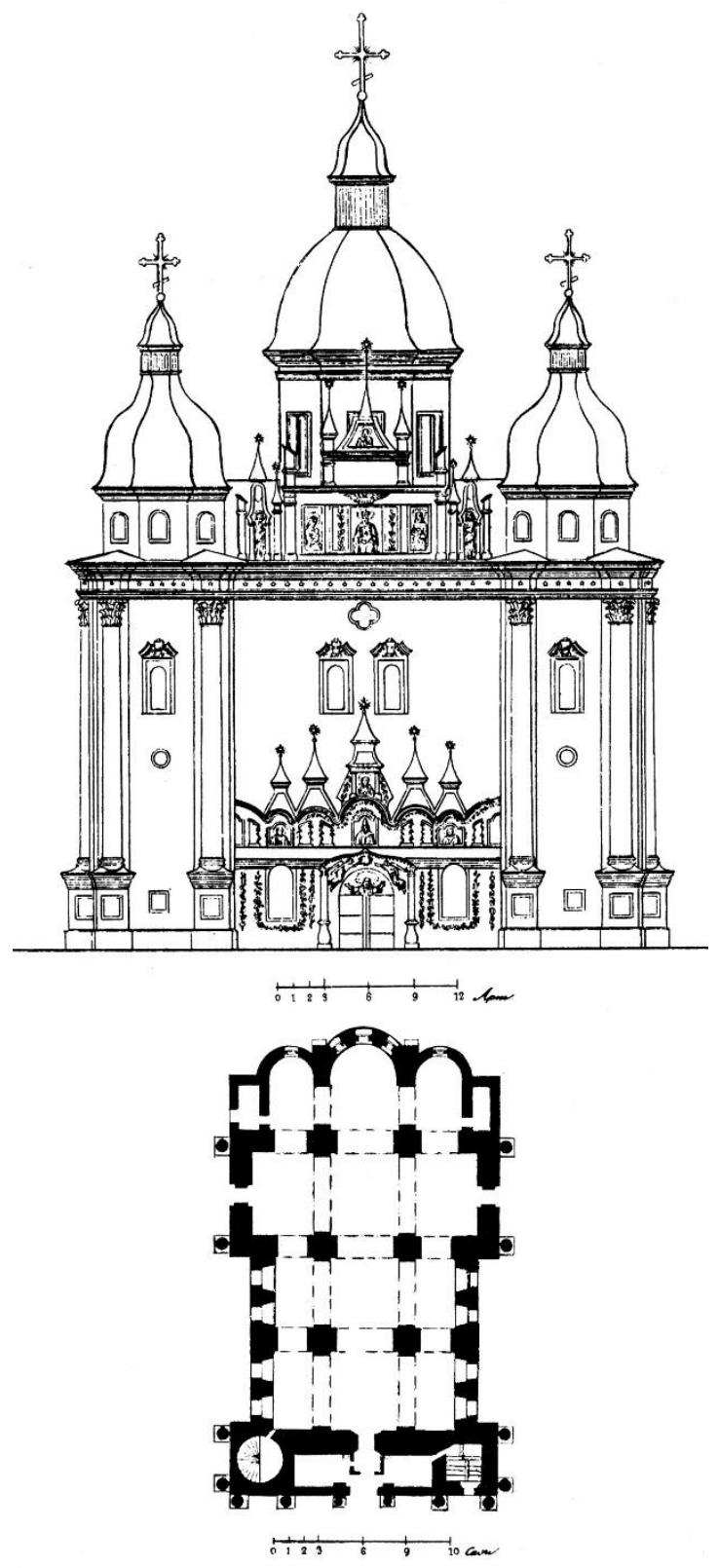

Fig. 7. Western facade and plan of the St. Nicholas (Military) Cathedral in Kyiv 
The second typological group of temples concerns with the development of volumetric and spatial compositions which were typical for Ukrainian wooden monumental architecture of the previous periods. The peculiarity of the time of Hetmante was that temples of this typological type developed rapidly and assumed the dominating positions both in stone and in wooden construction (Fig. 8, 9). They can be divided in two subtypes: triadic and cross-centric (Fig. 10, 11).

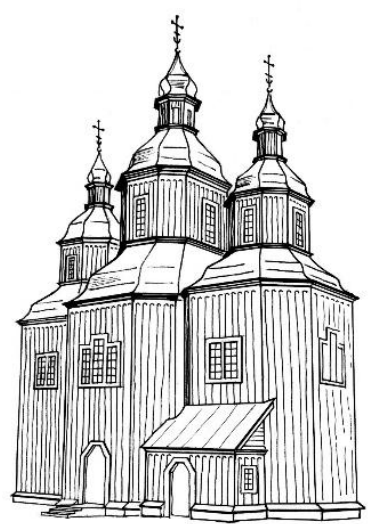

Fig. 8. A sample of a wooden triadic three domed church:

St. Nicholas Church in the village Gorodyshche in Chernihiv region.

Reconstruction of the original form by V. Vechersky

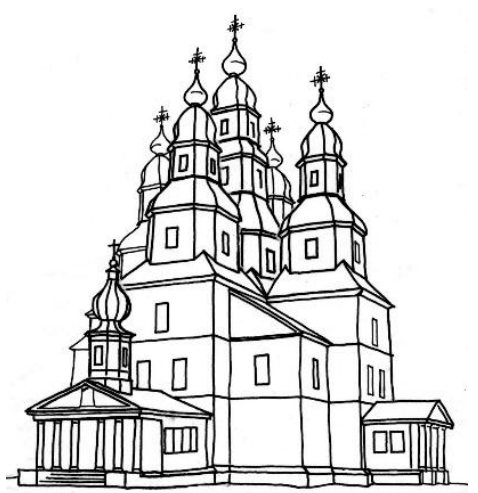

Fig. 10. A sample of a wooden crosscentric five domed church: Nicholas

Cathedral of the Medvedivsky Monastery near Chyhyryn. Drawing by $\mathrm{V}$. Vechersky

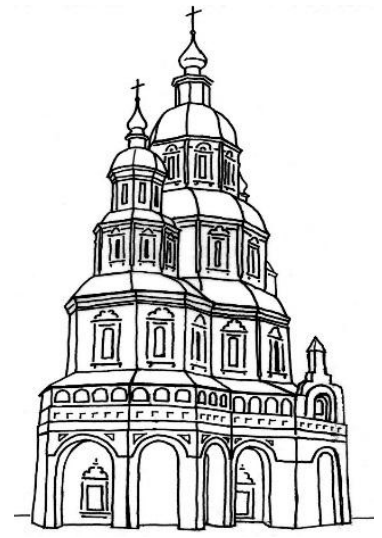

Fig. 9. A sample of a stone triadic three domed church: Pokrovsky Cathedral in Kharkiv. Drawing by V. Vechersky

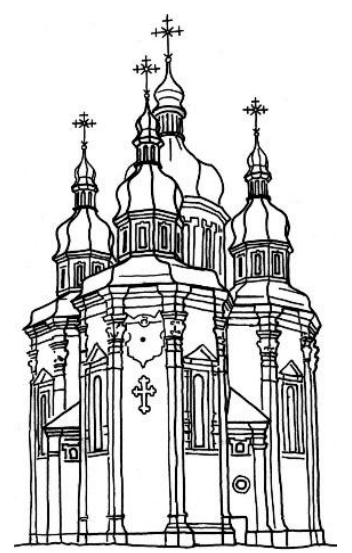

Fig. 11. A sample of a stone crosscentric five domed church: St. George's Cathedral of the Vydubitsky Monastery in Kyiv. Drawing by $\mathrm{V}$. Vechersky 
In non-Orthodox ecclesiastic architecture of the period tendencies of retrospectivism, especially inherent for Judaic sacral architecture, prevailed. Almost literal repeating of Central European standards was typical for Catholic ecclesiastic construction (Fig. 12) (Hornung, 1995, p. 154-162). Thus, we can describe Catholic and partly Uniate ecclesiastic architecture in Ukraine as provincial branch of Catholic-European one without outstanding national or regional distinctions and signs.

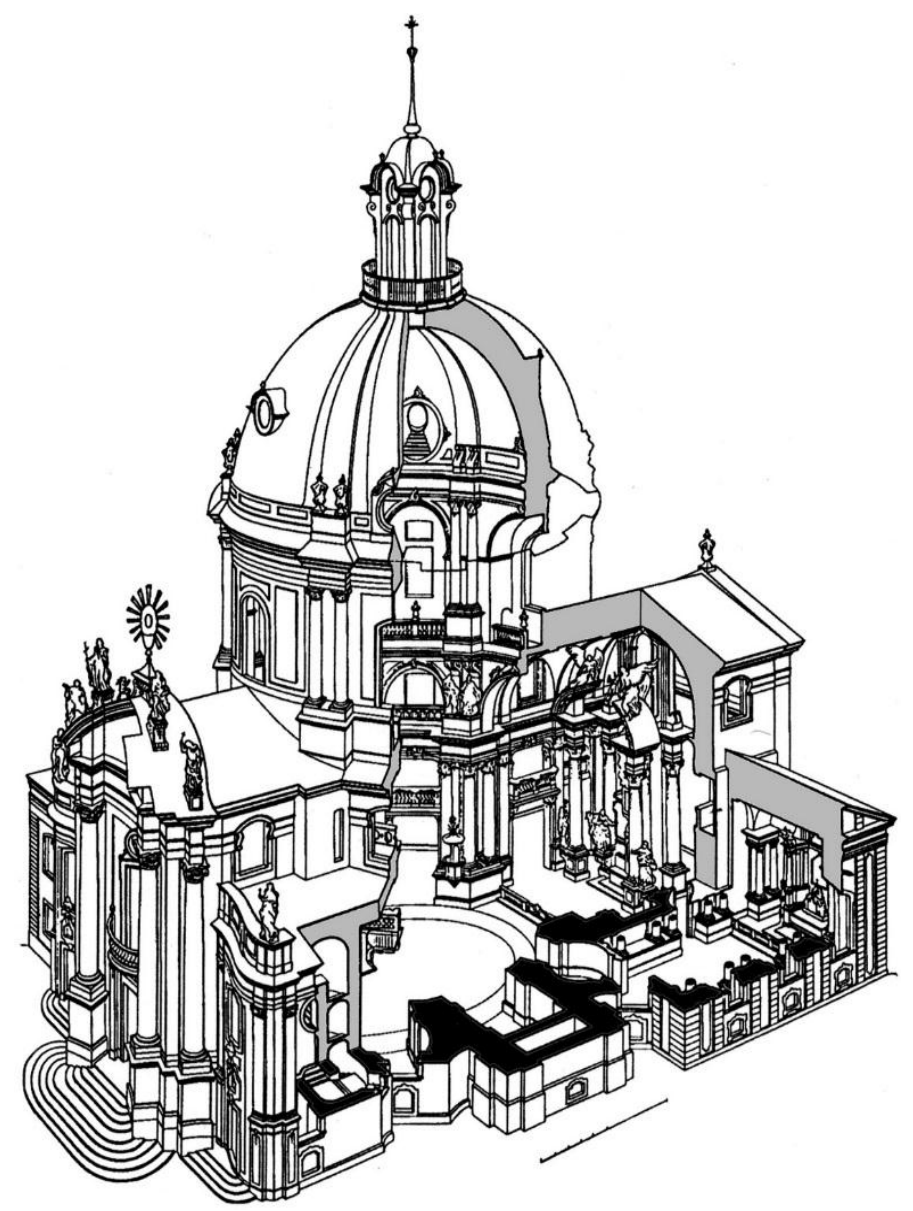

Fig. 12. Dominican Roman Catholic Church in Lviv. Axonometric section by S. Horung

In this respect, Orthodox sacral architecture of this period differs greatly in its planning and spatial typology from Catholic one, since it is original Ukrainian contribution to the world architectural treasury.

Besides main types of ecclesiastic_buildings which were the most popular and determined the course of architectural development in the time of Hetmanate, the significant development of the marginal types of constructions 
and different typological contamination was typical for that time. Among Orthodox temples we assign domeless ones of chamber type (Fig. 13), temples
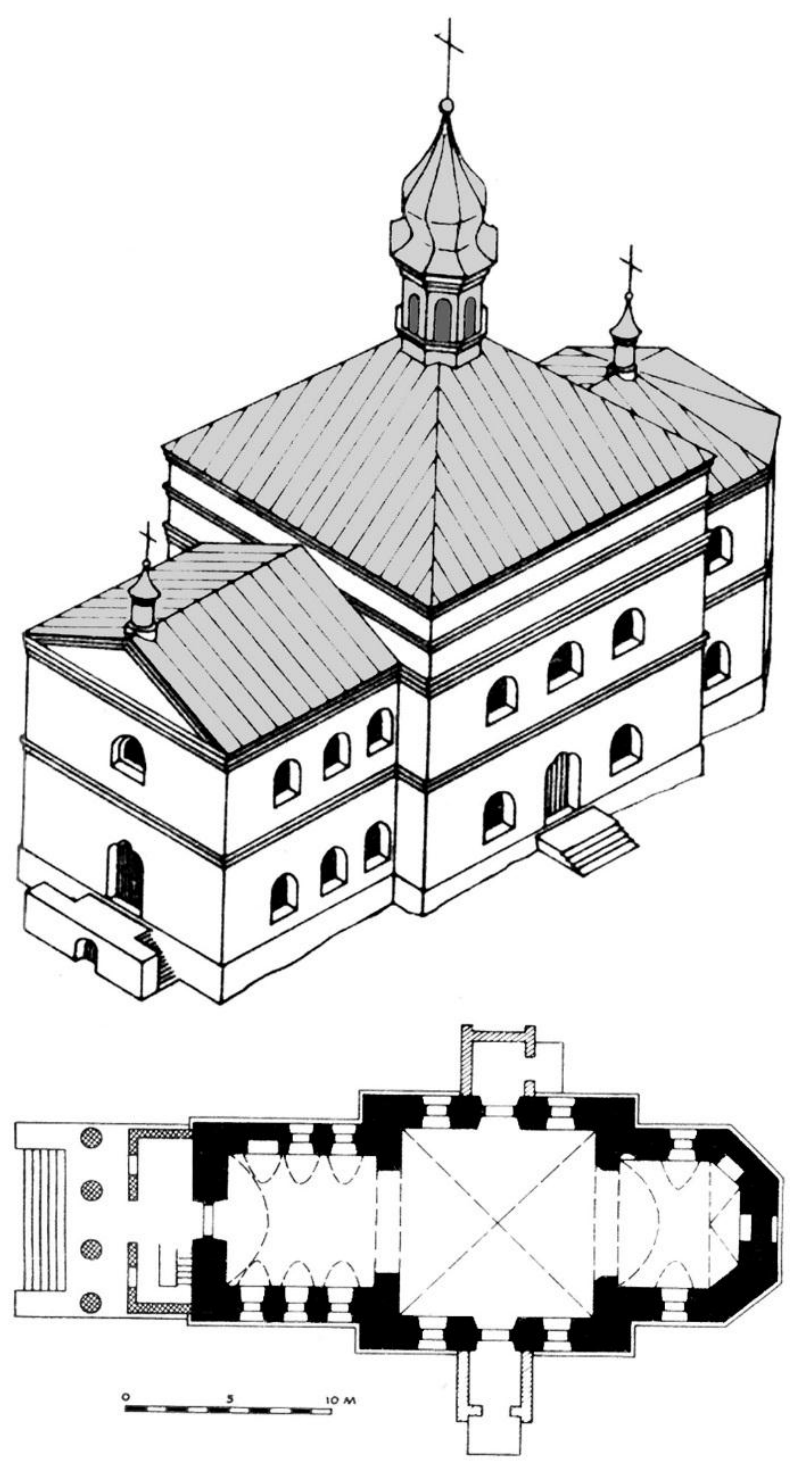

Fig. 13. A sample of the domeless chamber type church:

St. Michael's Church in the village Great Listven in Chernihiv region.

Plan and reconstruction of the original form by $\mathrm{V}$. Vechersky

with counter-apse, triconches (Fig. 14), tetraconches (Fig. 15), rotundas, tower-like to marginal types. The buildings which combine in their structure the different combinations of the main planning and spatial types: cross-domed type with triadic triple-domes or triadic with triconches belong to typological contaminations. 


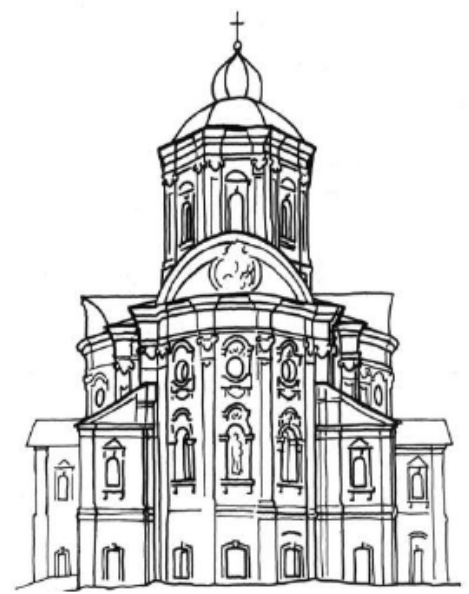

Fig. 14. A sample of the counter-apse triconch church:

St. Michael's Church in the village Voronizh in Sumy

region.
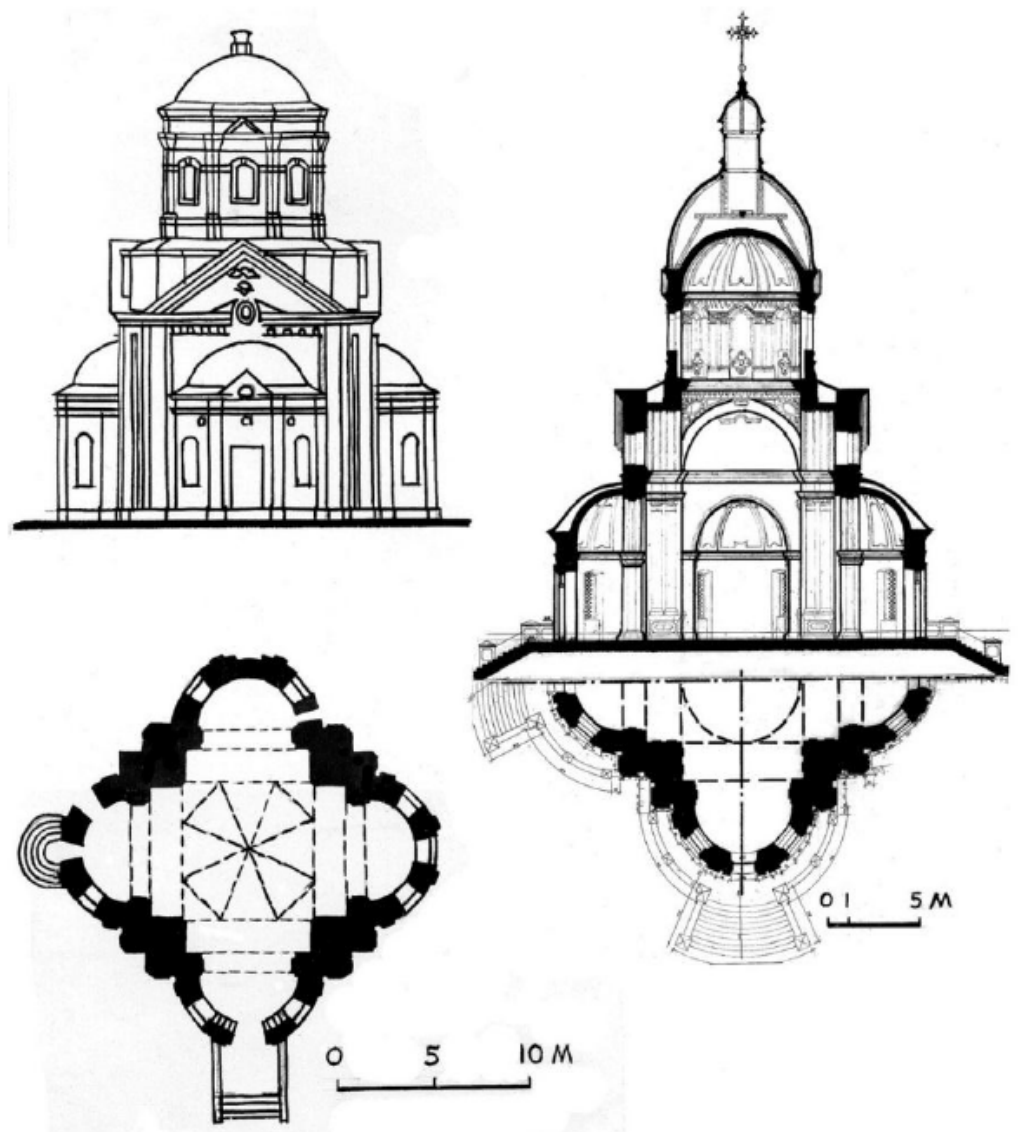

Fig. 15. Samples of the tetraconch church: the facade and the plan of the Ascension Church in Korop and the section and plan of the Church of the Three Saints in the village Lemeshi in Chernihiv region. 
The marginal types of sacral buildings along with more prevailing crossdomed type connect Ukrainian architecture with European one both with GreekOrthodox and Roman Catholic cultural spheres. Marginal types of temples and typological contaminations played an important part in the architectural development. Architectural thought worked actively over the established marginal types, adapting them to the traditional local architecture. At the same time, the typological contaminations were the object for innovative searching in the field of typology, constructions, tectonics and new figurativeness. Nevertheless, these searches came to an end in view of Russian Emperor's veto about Ukrainian national architecture.

Innovations in constructive and technical peculiarities of constructing the buildings in the period under consideration were caused by the development of their planning, volumetric and spatial structures. This greatly influenced the architectural and plastic solutions for which are typical the following features: predominance of volumetric compositions instead of frontal-plane ones; centric and hierarchical forms; the combining the vividness of silhouettes and forms that guaranteed the consistency of architectural form and clarity of its visual perception; tectonics based on the architectural order interpreted in a noncanonic way (decorative and symbolic); using the same plastic means for the buildings of all functional types.

We can clearly define two stylistic trends in Ukrainian architecture of the period under consideration: the local branch of Baroque in western regions; the development of style considerably different from Baroque in the Dnieper region, Left-bank Ukraine and Sloboda Ukraine. The architectural style of that period which is traditionally called "Ukrainian Baroque" has significant differences from European Baroque. In spite of the penetration of Baroque style and even Rococo (in the end of the period), Ukrainian architecture developed its own principles both in typology and in architectural-plastic solutions. Therefore, architecture of that period shows an original, deeply national synthesis in the context of chronological retardation on Ukrainian territories of both European styles (Renascence and Baroque).

Architectural heritage is spread very irregularly in Ukrainian regions that reflects the real irregularity of processes of architectural development. The most objects are concentrated in the Middle Dnieper region, Northern Left-bank Ukraine and Galicia; and the least - on the South of Ukraine (The State Register of the National Heritage, 1999).

We can observe drastic distinctions in town-planning of the West and East of Ukraine during all the period of Hetmanate. The main difference between town-planning of Eastern Ukraine and town-planning of Right-bank and Western Ukraine is the absence of so-called Magdeburg regular planning structures of town centers. At the time regular towns-fortresses (the latter half of XVIII century), having appeared as a result of Russian expansion into Northern Black Sea region, became the outstanding innovation on the South of Ukraine. These towns-fortresses continued the Renascence tradition of "ideal towns" popular in 
XVI-XVII centuries in Western Ukraine. Geopolitical changes caused the certain unification of planning and spatial arrangement of town-planning formations in the end of the period.

The regional distinctions are very outstanding and vivid in the folk monumental, first of all ecclesiastic, architecture; they increased in the end of the period. In spite of this fact, the features of commonality in these regional schools are more significant than differences, especially in the field of typology. It bears evidence of Ukrainian architectural unity within all Ukrainian ethnic territory. The folk architecture influenced mainly the formation of regional specific character of the stone elitist architecture in the Dnieper region, Left-bank Ukraine and Sloboda Ukraine. In contrast to these regions the stone elitist architecture concerned with Catholic cultural sphere was more cosmopolitan and unified in Right-bank and Western Ukraine.

\section{Conclusions and recommendations for further research in this direction.}

We consider Ukrainian architecture as independent phenomenon in contrast to works of previous researchers where they regarded it as the derivative from the architecture of Muscovy, Russian empire or as marginal phenomenon of the Central European architectural process. We proved the high level of self-sufficiency of Ukrainian architecture on the basis of development and transformation of indigenous traditions and selective adoption of the other cultures experience. We drew a conclusion that Ukrainian architecture in the period under consideration was not the provincial branch either Polish or Russian or any other architecture.

We revised the erroneous views and ideas present in science about the architecture of that period, in particular the definition about prevailing stylistics of architecture as Baroque. It is proved that two stylistic tendencies existed at that time - strictly Baroque of Western origin and synthesis of Renascence and Baroque which was caused by the development of indigenous architectural traditions. At the same time it is shown that the Renascence traditions of that period are based not only on the influences of Italian (Austrian, German, Polish, Lithuanian) Renascence, but also on the revival of "its antiquity" - the heritage of architecture of Kyivan Rus.

We clarified the regional irregularity of architectural development in the given period. We proved the existence of unified region where the architecture and town-planning at the initial stage of the period under consideration (Leftbank Ukraine including Sloboda Ukraine) with the center in Kyiv were the most strongly developed, and appearance of several such regions and centers in the end of the period which is an evidence of territorial equation of architectural processes activity.

The artistic genious of Ukrainian people is clearly shown in the architectural monuments in the times of Hetmanate. The mastering of European artistic heritage and further development of indigenous volumetric and spatial compositions enabled to synthesize the unique national style which became the significant contribution of Ukraine to the treasury of world architecture. 


\section{REFERENCES}

Ernst, F.L. (1919). Ukrainian art of the XVII-XVIII centuries. Kyiv [in Ukrainian].

From the History of Ukrainian Restoration. (1996). Kyiv: Ukrainoznavstvo [in Ukrainian].

Hornung, Z. (1995). Jan de Witte architekt kosciola dominikanow we Lwowie [Jan de Witte, architect of the Dominican church in Lviv]. Warsaw [in Polish].

Hrabar, I.E. (1997). Wooden Church Architecture of Precarpathian Rus. Pamiatky Ukrainy: istoriia ta kultura, 2, 60-66 [in Ukrainian].

International Conference on the Problems of Fortifications in Ukraine: Materials (1993). Kamyanets-Podilsky [in Ukrainian].

Kilesso, S.K. (2000). Architectural and Artistic Treasures of Bogdan's Land. Kyiv: Tekhnika [in Ukrainian].

Kilesso, T.S. (1995). Kyiv Architectural School of the Ukrainian Baroque. In Architectural heritage of Ukraine. (Issue 2, pp. 201-206). Kyiv: Ukrainoznavstvo [in Ukrainian].

Kluckert, E. (2008). Art and Architecture in the 17th and 18th Centuries Baroque and Rococo. In Vienna: Art and Architecture. Vienna: Ullmann Publishing [in English].

Lenchenko, V.O. (1997). Architecture of XVI-XVIII centuries in Ukraine. In Archeology of the Ukrainian Cossacks of the XVI-XVIII centuries (pp. 135-156). Kyiv: IZMN [in Ukrainian].

Lohvyn, G.N. (2002). Stylistic features of architecture and monumental and decorative art of the Ukrainian Baroque. In Architectural heritage of Ukraine. (Issue 5, pp. 74-81). Kyiv: NDITIAM [in Ukrainian].

Makarenko, M.O. (1908). Monuments of the Ukrainian art of the XVIII century: A separate print from the magazine "Zodchyi" [in Russian].

Norwich, J. (1979). Great Architecture of the World. London: Mitchell Beazley Publishers [in English].

Ohloblyn, O.P. (2008). Western Europe and the Ukrainian Baroque: an Aspect of Cultural Influences at the Time of Hetman Ivan Mazepa. In Baturynska starovyna: Collection of scientific works devoted to the 300th anniversary of the Baturin tragedy. Kyiv: Olena Teliga Publishing House.

Pavlutsky, G.G. (2017). Wooden and masonry temples of Ukraine. Kharkiv: Publisher Oleksandr Savchuk [in Ukrainian].

Prybeha, L.V. (2007). Wooden temples of the Ukrainian Carpathians. Kyiv: Tekhnika [in Ukrainian].

Shcherbakivsky, V.M., \& Shcherbakivsky, D.M. (2015). Ukrainian art. Kharkiv: Publisher Oleksandr Savchuk [in Ukrainian].

Sichynsky, V.E. (1956). Architecture. In History of Ukrainian Art. (Vol. 1). New York: Shevchenko Scientific Society [in English].

Taranushenko, S.A. (2014). Wooden Monumental Architecture of the Left Bank Ukraine. Kharkiv: Publisher Oleksandr Savchuk [in Ukrainian].

The State Register of the National Heritage (Monuments of Architecture and Urbanism). (1999). Pamiatky Ukrainy: istoriia ta kultura, 2-3, 1-176 [in Ukrainian].

Tsapenko, M.P. (2005). Prominent buildings of the Northern Hetmanate. Pamiatky Ukrainy: istoriia ta kultura, 1, 95-103 [in Ukrainian].

Tymofiienko, V.I. (Eds.). (2003). The History of Ukrainian Architecture. Kyiv: Tekhnika [in Ukrainian].

Ukrainian Culture of the second half of XVII-XVII centuries. (2003). In The History of Ukrainian Culture in 5 volumes. (Vol. 3). Kyiv: Naukova dumka [in Ukrainian]. 
Victor Vechersky: Biographical and bibliographical index. Graphics (2008). Kyiv: ArtEk [in Ukrainian].

Yablonsky, D.N. (1955). Portals in Ukrainian architecture. Kiev: Publishing house of the Academy of Architecture of the USSR [in Russian].

Yurchenko, P.G. (1970). Wooden Architecture of Ukraine. Kyiv: Budivelnyk [in Ukrainian].

Yurchenko, S.B. (2015). Several Documents on the Activities of Andriy Kvasov in Hlukhiv. In Sivershchyna in the History of Ukraine. Collection of scientific work. (Issue 8, pp. 14-24). Kyiv: Center for Memory Studies of National Akademy of Science of Ukraine and UTOPIK [in Ukrainian].

\title{
УДК 725(477)"16/17"
}

\author{
Віктор Вечерський, \\ кандидат архітектури, доцент, \\ Київський національний університет \\ культури і мистецтв, \\ Київ, Україна \\ vechersky.v@gmail.com \\ https://orcid.org/0000-0002-5221-3556
}

\section{РЕЗУЛЬТАТИ ДОСЛІДЖЕННЯ УКРАÏНСЬКОÏ АРХІТЕКТУРИ ДОБИ ГЕТЬМАНЩИНИ}

Стаття присвячена підсумкам наукових досліджень архітектури України XVII-XVIII ст., здійснених протягом останнього століття. Актуальність дослідження зумовлена необхідністю формування історії вітчизняної архітектури та пам'яткознавства на сучасних методологічних засадах, згідно з ними вивчаються всі явища і процеси відповідної доби в межах сучасної території держави, незалежно від етнічного, конфесійного чи державного походження тих чи інших явищ і артефактів. Метою дослідження $€$ узагальнення результатів вивчення історико-архітектурного процесу у добу Гетьманщини, у т. ч. уточнення етапів розвитку архітектури; виявлення регіональних особливостей; встановлення ролі імісця архітектурної спадщини доби Гетьманщини в подальшому розвитку української архітектури та урбаністики та ї̈ місця в контексті розвитку європейської архітектури. Методологія дослідження полягає в застосуванні методів теоретичних досліджень, а саме історичного методу при системному підході, коли об'єкт вивчення - архітектура певної епохи - розглядається у виникненні і розвитку. Системний підхід полягає в комплексному вивченні об'єкта як певної єдності багатоелементної системи, для вивчення якого застосовано методи структурно-генетичного аналізу та синтезу з декомпозицією системи на підсистеми, які досліджуються автономно, з подальшим їх узгодженням. Наукова новизна полягає у виявленні закономірностей становлення і розвитку архітектури України в добу Гетьманщини, визначенні характеру та основних особливостей цих процесів, з'ясуванні регіональних відмінностей, визначенні європейського та євразійського контексту розвитку архітектури в тогочасній Україні. Результати і висновки дослідження дозволяють розглядати архітектуру України як самостійне явище, а не як похідну від архітектури Московського царства, Російської імперії чи маргінальне явище 
центральноєвропейського архітектурного процесу. Доведено високий рівень самодостатності української архітектури на основі розвитку і трансформації автохтонних традицій та вибіркового засвоєння досвіду інших культур. Переглянуто наявні в науці некоректні уявлення щодо визначення панівної стилістики архітектури як барокової. Доведено одночасне існування двох стильових течій - суто барокової, західного походження, і ренесансно-барокового синтезу, що став наслідком розвитку автохтонних архітектурних традицій.

Ключові слова: архітектурна спадщина, доба Гетьманщини, історія архітектури, етапи розвитку, європейський контекст.

\section{УДК 725(477)"16/17"}

\section{Виктор Вечерский,}

кандидат архитектуры, доцент,

Киевский национальный университет

культуры и искусств,

Киев, Украина

vechersky.v@gmail.com

https://orcid.org/0000-0002-5221-3556

\section{РЕЗУЛЬТАТЫ ИССЛЕДОВАНИЯ УКРАИНСКОЙ АРХИТЕКТУРЫ ЭПОХИ ГЕТМАНЩИНЫ}

Статья посвящена итогам научных исследований архитектуры Украины XVII-XVIII вв., которые проводились на протяжении последнего столетия. Актуальность исследования обусловлена необходимостью формирования истории отечественной архитектуры и памятниковедения на современных методологических принципах, согласно которым изучаются все явления и процессы соответствующей эпохи в пределах современной территории государства, независимо от этнического, конфессионального или государственного происхождения тех или иных явлений и артефактов. Целью исследования является обобщение результатов изучения историкоархитектурного процесса в эпоху Гетманщины, в т. ч. уточнение этапов развития архитектуры; выявление региональных особенностей; установление роли и места архитектурного наследия эпохи Гетманщины в дальнейшем развитии украинской архитектуры и урбанистики и ее места в контексте развития европейской архитектуры. Методология исследования заключается в применении методов теоретических исследований, а именно исторического метода при системном подходе, когда объект изучения - архитектура определенной эпохи рассматривается в возникновении и развитии. Системный подход заключается в комплексном изучении объекта как определенного единства многоэлементной системы, для изучения которого применены методы структурно-генетического анализа и синтеза с декомпозицией системы на подсистемы, которые исследуются автономно, с последующим их согласованием. Научная новизна заключается в выявлении закономерностей становления и развития архитектуры Украины в период Гетманщины, определении характера и основных особенностей этих процессов, выяснении региональных различий, определении европейского и евразийского контекста развития архитектуры в тогдашней 
Украине. Результаты и выводы исследования позволяют рассматривать архитектуру Украины как самостоятельное явление, а не как производную от архитектуры Московского царства, Российской империи или маргинальное явление центральноевропейского архитектурного процесса. Доказан высокий уровень самодостаточности украинской архитектуры на основе развития и трансформации автохтонных традиций и выборочного усвоения опыта других культур. Пересмотрены имеющиеся в науке некорректные представления по определению господствующей стилистики архитектуры как барокко. Доказано одновременное существование двух стилевых течений - чисто барочного, западного происхождения, и ренессансно-барочного синтеза как следствия развития автохтонных архитектурных традиций.

Ключевые слова: архитектурное наследие, период Гетманщины, история архитектуры, этапы развития, европейский контекст.

(c) Вечерський В., 2018 